\title{
Exploring the Nexus of Water Contamination, Health Hazards and Households' Knowledge: A Pilot Study in Rawalpindi, Pakistan
}

Yasir Mehmood, Abdul Qadar

\begin{abstract}
Objective: To examines factors affecting households' knowledge regarding water contamination and identify health issues related to drinking contaminated water.

Study Design: Cross-sectional study.

Place and Duration of Study: The information was collected from the households living in the surroundings of the Lai sewer of Rawalpindi city, from August 2019 to December 2019.

Materials and Methods: One hundred and sixty-two (162) households were randomly selected and interviewed using a well-structured questionnaire for pre-testing. The Ordered Logit model was used to analyze the data and identify determinants affecting households' knowledge regarding water contamination.

Results: The education level of households, income, proximity to the Lai sewer, health issue, and access to health advice had significant positive effects on their knowledge regarding water contamination. The study showed that vomiting (51.67\%), abdominal pain (48.19\%), and diarrhea (42.68) were the main health issues reported by the households.
\end{abstract}

Conclusion: Effective community awareness programs regarding hazards of water contamination are important to prevent adverse health outcomes.

Key Words: Environment, Ground Water, Health Hazards, Knowledge, Pakistan.

How to cite this: Mehmood Y, Qadar A. Exploring The Nexus Between Water Contamination, Health Hazards and Households' Knowledge: A Pilot Study in Rawalpindi, Pakistan. Life and Science. 2021; 2(2):44-48. doi: http://doi.org/10.37185/LnS.1.1.118

This is an Open Access article distributed under the terms of the Creative Commons Attribution License (http://creativecommons.org/licenses/by/4.0), which permits unrestricted use, distribution, and reproduction in any medium, provided the original work is properly cited.

\section{Introduction}

Equitable access to safe drinking water is considered one of the biggest challenges the world is facing from the last few decades. ${ }^{1}$ According to the World Health Organization (WHO) fact sheet on water issues, around 780 million of the world's population lacks access to clean and safe drinking water, while at least 2 billion people consuming water contaminated with feces, pathogens, and other toxic metals. ${ }^{2}$ Though United Nations and other development organizations have been putting in many efforts to provide safe drinking water, yet millions of people suffer with lack of access to safe water facilities,

Department of Social and Behavioral Sciences

National University of Medical Sciences, Rawalpindi

Correspondence:

Dr. Yasir Mehmood

Assistant Professor, Social and Behavioral Sciences

National University of Medical Sciences, Rawalpindi

E-mail: yasir.mehmood@numspak.edu.pk

Funding Source: NIL; Conflict of Interest: NIL

Received: May 04, 2020; Revised: Jan 18, 2021

Accepted: Feb 22, 2021

44 even when many countries pledged implementation of Millennium Development Goals (MDGs). ${ }^{3}$ One of the main purpose of MDGs was to provide adequate access to safe water to half of the world's population till the end of $2015{ }^{3}$ but regrettably, it could not be achieved. The agenda of Sustainable Development Goals (SDGs) also focused to "ensure availability of clean water for all". ${ }^{4}$

Like other low-income countries, Pakistan is facing acute water shortages, and the available water resources in the country are loaded with toxic metals and other sorts of contaminations including microbiological. ${ }^{5}$ The availability of supplied water in the country, is through few water filtration plants which are installed in some megacities, and they are supplying water in specific areas with undetected microorganisms. As a result, a greater majority of the population in the country is deprived of safe water supply. The study by Amin et al. (2012) ${ }^{6}$ noted that around 70 percent of the rural population and $40-60$ percent of the urban population in Pakistan are 
deprived of safe water. In another report, published by the Pakistan Council of Research in Water Resources (PCRWR), around 85 percent of the water sources in Pakistan are below the recommended quality standards prescribed by the WHO. ${ }^{7}$ Pakistan Strategic country environmental assessment (PAKSECA) report indicates that 20-40 percent of hospital beds in Pakistan are occupied by patients suffering from waterborne diseases, while around 30 percent of all deaths in the country occur because of water contamination related diseases. ${ }^{8}$

A greater percentage of the population in Pakistan is living in informal settings and has inadequate information about water contamination and hygiene. This gap regarding knowledge about water contamination is linked with several factors including socio-economic, socio-psychological, and cultural factors, ${ }^{9,10}$ which are seldom taken into account. The previous literature (Kazi et al., 2009; Marlow et al., 2013; Tang et al., 2013; Ahmed and Shafiq 2019; among others) ${ }^{11,1,12,13}$ has shown that the first step towards sustainable water management and consumption is to create knowledge and awareness among the citizenries. Indeed, knowledge is a central model of environmental literacy and water-related issues. ${ }^{14,9,15}$ Davies and Simon $(2012)^{16}$ claimed that greater knowledge allows an individual to solve the environmental problem by making better decisions. ${ }^{5}$ The authors understand that analyzing the factors affecting households' knowledge are substantial, considering several reasons such as increasing knowledge may improve the households' positive attitudes and guide to adopt the safety measures. Considering the paramount importance, the aim of this study was to analyze the factors affecting households' knowledge of water contamination and identify deleterious health risks associated with the use of contaminated water. We hypothesize that health impact and access to health advice increases households' knowledge related to water contamination.

The study was conducted in the surroundings of the Lai sewer of Rawalpindi city. The Lai sewer is a natural rain-fed stream originating from the Margallah Hills of Islamabad. It has a catchment area of around 240 kilometers which brings water domestic sewage, industrial wastewater, and rainwater runoff from twin cities spreading environmental pollution and deteriorating groundwater resources. Haq et al. $(2008)^{17}$ conducted a study on water testing of tube wells and reported that out of 240 tube wells in the vicinity of the Lai sewer, 72 tube wells were biologically and chemically contaminated and the main reason for this contamination was the recharge mechanism of the Lai sewer and Korang River. ${ }^{17}$

\section{Materials and Methods}

This is a pilot study of a detailed research project aiming to analyze cross-sectional data collected from the households residing near the Lai Sewer of Rawalpindi City from August 2019 to December 2019. Our focus in this study is on health hazards and water contamination. A total of 162 respondents were selected randomly from three different areas of Lai sewer. A well-structured and pre-tested questionnaire was used to collect the desired information on socioeconomic characteristics, water quality, availability and diseases associated with water pollution, etc.

The dependent variable shows households' knowledge of water contamination using a five-point Likert scale ( 1 = strongly disagree; $5=$ strongly agree). The dependent variable was ordinal, therefore, the Ordered Logit model was considered to analyze the effect of other factors on households' knowledge of water contamination. Following the method used by Mehmood et al. $(2020)^{18}$ the probability that household $i$ takes on the value (Yi) when household $i$ faces the $j^{\text {th }}$ ordered category for $j=1, \cdots, M$, where $M$ is considered as different ordinal responses of the household as mentioned earlier. The Ordered Logit model is given as under:

$\mathrm{P}\left(\mathrm{Y}_{\mathrm{i}}>j\right)=f\left(\mathrm{X}_{\mathrm{i}} \beta\right)=\frac{\exp \left(\alpha_{j}+\mathrm{X}_{\mathrm{i}} \beta\right)}{1+\exp \left(\alpha_{j}+\mathrm{X}_{\mathrm{i}} \beta\right)}$ for $j=1, \ldots . ., M-1$

where $P(\cdot)$ in equation (1) is considered as the probability, while $f(\cdot)$ represents the probability density function, $\mathrm{Xi}$ is a vector of independent variables for households, where I $\alpha$ and $\beta$ and in the equation represent cut-off and slope parameters, respectively. The Ordered Logit model supposes that cut-off parameters (aj) change over $\mathrm{j}=1, \cdots, \mathrm{M}-1$ different alternative compared with the slope parameters ( $\beta$ ) that do not vary. It has been generally argued that parallel line assumptions are generally violated while empirical applications of the ordered logit model. Therefore, to relax the parallel-lines 
assumption, Williams $(2006)^{19}$ introduced the generalized Ordered Logit model, which is given as under:

$\mathrm{P}\left(\mathrm{Y}_{\mathrm{i}}>j\right)=f\left(\mathrm{X}_{\mathrm{i}} \beta_{\mathrm{j}}\right)=\frac{\exp \left(\alpha_{j}+\mathrm{X}_{\mathrm{i}} \beta_{\mathrm{j}}\right)}{1+\exp \left(\alpha_{j}+\mathrm{X}_{\mathrm{i}} \beta_{\mathrm{j}}\right)}$ for $j=1, \ldots ., M-1$

The dependent variable in the generalized ordered logit model allows the slope parameters $\beta \mathrm{j}$ to vary over each category. The probabilities in this model are express as:

$$
\begin{aligned}
& P\left(Y_{i}=1\right)=1-F\left(X_{i} \beta_{1}\right) \\
& P\left(Y_{i}=j\right)=F\left(X_{i} \beta_{j-1}\right)-F\left(X_{i} \beta_{j}\right) \text { for } j=2, \ldots, M-1 \\
& P\left(Y_{i}=M\right)=F\left(X_{i} \beta_{M-1}\right)
\end{aligned}
$$

where $F(\cdot)$ in equation (3) is considered as the aggregate density function of the normal logistic distribution. Positive parameters in the equation show that the value of the independent factor increases the probability that the households considered water contamination as highly risky for health. On the contrary, negative parameters show that the value of the independent factors decreases the probability that the household is considered as not risky for health.

The dependent variable is considered as binary variable i.e., one for those households knowing water contamination and zero for else. Eight explanatory variables include the age of the household's head (years), family size (numbers), the education level (formal years of education in years), income (calculated in the US dollar.), proximity to the Lai sewer (meters), residence period near Lai sewer (years), access to advice (1 for the households receive information from the community about water contamination in the area, otherwise 0 ), and health impacts ( 1 for the households suffered any adverse health effect, otherwise 0 ). It is hypothesized that having adverse health impacts will increase the household's knowledge of water contamination.

\section{Results}

The empirical estimates of the households' knowledge of water contamination are shown in Table 1 . The results of the ordered logistic model show that households' education, income, proximity to the Lai sewer, access to advice, and health impact are significantly related to the households' knowledge of water contamination. The significant relationship between the households' knowledge and the variables are represented through the values of coefficients: educational level $(\beta=0.071)$, income $(\beta=0.002)$, proximity to the Lai Sewer $(\beta=-0.007)$, access to advice $(\beta=0.229)$, and health impact $(\beta=$ $0.818)$. The results further explain that the variable of education, proximity to the Lai sewer, access to advice were significant at a $5 \%$ level of significance, respectively, while the income of the households' head was at $10 \%(p<0.10)$ level of significance. The results of this study are supported by the empirical evidence of Ahmed and Shafiq (2019). The goodness of fit of the ordered logit model can be observed

\begin{tabular}{|c|c|c|c|c|c|c|}
\hline & Coefficient & $\begin{array}{l}\text { Std. } \\
\text { Error }\end{array}$ & $P$-value & & $\begin{array}{l}\text { Lower } \\
\text { bound }\end{array}$ & $\begin{array}{l}\text { Upper } \\
\text { bound }\end{array}$ \\
\hline $\begin{array}{l}\text { Age of the } \\
\text { respondent }\end{array}$ & 0.015 & 0.011 & 0.163 & & $\begin{array}{c}- \\
0.006\end{array}$ & 0.038 \\
\hline Family size & 0.100 & 0.038 & 0.791 & & $\begin{array}{c}- \\
0.064\end{array}$ & 0.084 \\
\hline $\begin{array}{l}\text { Education } \\
\text { level }\end{array}$ & 0.071 & 0.031 & 0.021 & $*$ & 0.011 & 0.132 \\
\hline Income & 0.002 & 0.001 & 0.072 & $*$ & $\begin{array}{c}- \\
0.000\end{array}$ & 0.005 \\
\hline $\begin{array}{l}\text { Proximity } \\
\text { to the Lai } \\
\text { sewer }\end{array}$ & -0.006 & 0.002 & 0.008 & * & $\begin{array}{c}- \\
0.008\end{array}$ & $\begin{array}{c}- \\
0.001\end{array}$ \\
\hline $\begin{array}{l}\text { Residence } \\
\text { period }\end{array}$ & 0.002 & 0.009 & 0.782 & & $\begin{array}{c}- \\
0.016\end{array}$ & 0.021 \\
\hline $\begin{array}{l}\text { Access to } \\
\text { advice }\end{array}$ & 0.229 & 0.114 & 0.045 & $*$ & $\begin{array}{c}- \\
0.004\end{array}$ & 0.453 \\
\hline $\begin{array}{l}\text { Health } \\
\text { impact }\end{array}$ & 0.818 & 0.321 & 0.011 & $*$ & 0.118 & 1.448 \\
\hline
\end{tabular}
through the value of Pseudo's R2 measures (0.091) the log-likelihood statistics (-225), and LR X2 (45.63).

Note: ${ }^{*} P<0.10$ and ${ }^{* *} P<0.05$.

The questionnaire contains information about various waterborne related symptoms and diseases (Table 2), including abdominal pain (48.19\%), vomiting (51.67\%), constipation (22.33\%), diarrhea (42.68), renal problems (20.53), and hepatitis (35.33). Some of the respondents and their family members suffered more than one waterborne related symptoms and disease.

\section{Discussion}

Understanding the factors affecting households' 


\begin{tabular}{lc}
\hline \multicolumn{2}{l}{ Table 2: Symptoms and diseases suffered by the } \\
households due to water contamination (\%) \\
\hline Health Impacts & Total (83) \\
Abdominal pain & 48.19 \\
Vomiting & 51.67 \\
Constipation & 22.33 \\
Diarrhea & 42.68 \\
Renal problem & 20.53 \\
Hepatitis & 35.33 \\
Others & 15.21 \\
\hline
\end{tabular}

Note: Some households and their family members suffered more than one health issue

knowledge about water contamination is significantly important for designing policy and adopting precautionary measures for its execution. Our pilot study shows that education is an important factor to understand health and environmental issues. The study by Lee and Zhang (2008) ${ }^{20}$ and empirical evidence provided by Feng and Reisner $(2011)^{21}$ noted that education makes a person more knowledgeable and helps aware of a complex environmental phenomenon. This has been empirically analyzed in existing studies. ${ }^{22,23}$ For households in Rawalpindi city, a similar study by Ahemd and Shafiq (2018) ${ }^{11}$ analyzed a positive and significant relationship between education and households' knowledge. The coefficient of income was also found significant at a $10 \%$ level of significance. The study by Bjornlund et al. (2019) noted that a higher level of household income improves households' knowledge, awareness, and allows them to take better decisions. The price of bottled water in the area is much higher and it is difficult for those households who have a low level of income to afford it.

The positive effect of access to advice is significant because an increasing number of households spare a substantial proportion of their time in social gatherings and receive information about water contamination and health hazards. The majority of the surveyed households had no information about water contamination and its effect on health. The coefficient of proximity to the Lai sewer was significant at a $5 \%$ level of significance. This signifies that households residing near the Lai sewer had more knowledge of water contamination. Venables et al. $(2012)^{25}$ reported a significant and positive relationship between the household's knowledge and proximity to the pollution sources. The variable of health impact had a significant positive relationship with household knowledge. The results suggest that adverse health effect due to waterborne diseases are chronic in the affected communities near the Lai sewer which is in line with the studies by Kazi et al. (2009); Vorosmarty et al. (2010). ${ }^{11,22}$ Ahemd and Shafiq $(2018)^{1}$ reported that consumption of water contaminated with heavy metals and the pathogen harm blood circulation, heart, kidneys, and nervous system.

Moreover, the major diseases reported by the households in the area surveyed were vomiting (51.67\%), abdominal pain (48.19\%), and diarrhoea (42.68) (including dehydration and chronic diarrhoea). The present study did not explore the reasons for using contaminated groundwater. Further, the health costs of the households using groundwater were not estimated. Having this information would provide interesting results.

\section{Conclusion}

The assessment of the households' knowledge of water contamination is necessary for the consumption of safe drinking water. Indeed, the lack of households' knowledge makes them consume contaminated water, which increases the risk of adverse health impacts. The results of the Ordered Logit model indicate that education of the households, income, proximity to the Lai sewer, access to advice, and health impact significantly contribute to the households' knowledge of water contamination in the area surveyed.

\section{REFERENCES}

1. Kazi T, Arain M, Jamali MK, Jalbani N, Afridi H, Sarfraz R, et al. Assessment of water quality of polluted lake using multivariate statistical techniques: a case study. Ecotoxicol Environ Safe. 2009; 72: 301-9.

2. WHO, World Health Organization: 2019 [Available from https://ww w. who.int/news - room/fact sheets/detail/drinking-water].

3. United Nations. The millennium development goals report 2010, New York: United Nations; 2010.

4. Hering J, Maag GS, Schnoor JL. A call for synthesis of water research to achieve the sustainable development goals by 2030. Environ Sci Techn. 2016; 50: 6122-3.

5. Azizullah A, Khattak MNK, Richter P, Häder DP. Water pollution in Pakistan and its impact on public health-a review. Environ Inter. 2011; 37: 479-97.

6. Amin R, Ali SS, Anwar Z, Khattak JZK. Microbial analysis of drinking water and water distribution system in new urban Peshawar. Curr Res J Bio Sci. 2012; 4: 731-7.

7. PCRWR. National water monitoring programme 2002-6. 
Islamabad, Pakistan: Pakistan Council of Research in Water Resources; 2008.

8. Pak-SECA. Pakistan-Strategic country environmental assessment: Main report (English). Washington, D.C. : World Bank Group; 2006. tp://documents.world bank.org/curated/en/132221468087836074/Main-report

9. Dolnicar S, Hurlimann A, Grun B. Water conservation behavior in Australia. J Environ Manage. 2012; 105: 44-52.

10. Vorosmarty CJ, Mclntyre PB, Gessner MO, Dudgeon D, Prusevich A, Green P, et al. Global threats to human water security and river biodiversity. Nature. 2010; 467: 555-61.

11. Ahmed A, Shafique I. Perception of household in regards to water pollution: An empirical evidence from Pakistan. Environ Sci Pol Res. 2019; 26: 8543-51.

12. Marlow DR, Moglia M, Cook S, Beale DJ. Towards sustainable urban water management: a critical reassessment. Water Res. 2013; 47: 7150-61.

13. Tang J, Folmer $\mathrm{H}$, Xue J. Estimation of awareness and perception of water scarcity among farmers in the Guanzhong Plain, China, by means of a structural equation model, J Environ Manage. 2013; 126: 55-62.

14. Dobson A. Environmental citizenship: towards sustainable development. Sustain Dev. 2007; 15: 276-85.

15. Mehmood Y, Arshad M, Kaechele H, Mahmood N, Kong R. Pesticide residues, health risks, and vegetable farmers' risk perceptions in Punjab, Pakistan. Hum. Ecol. Risk. 2020; 26: 1-20.

16. Davies A, Simon J. The value and role of citizen engagement in social innovation'. A deliverable of the project: "The theoretical, empirical and policy foundations for building social innovation in Europe" (TEPSIE). European Commission- 7th Framework Programme, Brussels: European Commission, DG Research; 2012.

17. Haq IU, Cheema WA, Ahmed N. Securing Groundwater Quality in Urban and Industrial Environments (Proc. 6th International IAHS Groundwater Quality Conference, held in Fremantle, Western Australia, 2-7 December 2007).
Multifaceted ground water quality and recharge mechanism issues in a mega-city (Rawalpindi, Pakistan), and mitigation strategies; 2008.

18. Mehmood Y. Arshad M, Kaechele H, Mahmood N, Kong R. Pesticide residues, health risks, and vegetable farmers' risk perceptions in Punjab, Pakistan. Hum Ecol Risk Asses. 2020; 27:846-64.

19. Williams R. Generalized ordered logit/partial proportional odds models for ordinal dependent variables. Stata J. 2006; 6:58-82.

20. Lee HF, Zhang DD. Perceiving the environment from the lay perspective in desertified areas, northern China. Environ. Manage. 2008; 41: 168-82.

21. Feng $W$, Reisner $A$. Factors influencing private and public environmental protection behaviors: results from a survey of residents in Shaanxi, China. J. Environ. Manage. 2011; 92: 429-36.

22. Mehmood $\mathrm{Y}$, Kong R, Arshad M, Bashir MK. Do liquidity constraints influence the technical efficiency of wheat growers? Evidence from Punjab, Pakistan. J Anima Plant Sci. 2017; 27: 667-79.

23. Mehmood Y, Kong R, Bashir MK, Arshad M. Does partial quantity rationing of credit affect the technical efficiency of dairy farmers in Punjab, Pakistan: an application of stochastic frontier analysis. Brit Food J. 2018; 120: 441-51.

24. Bjornlund H, Zuo A, Wheeler SA, Parry K, Pittock J, Mdemu $M$, et al. The dynamics of the relationship between household decision-making and farm household income in small-scale irrigation schemes in southern Africa, Agricultural Water Management. 2019; 213: 135-45.

25. Venables D, Pidgeon NF, Parkhill KA, Henwood KL, Simmons P. Living with nuclear power: Sense of place, proximity, and risk perceptions in local host communities. J Environ Psychol. 2012; 32: 371-83. 